\title{
Religion and Democracy in the Thought of Jürgen Habermas
}

\author{
Philippe Portier
}

Published online: 28 July 2011

(C) Springer Science+Business Media, LLC 2011

Jürgen Habermas, Germany's most important living philosopher, has given considerable attention over his long career to the question of religion in modern society. His thought has not remained identical throughout, but has gone through three major phases.

The first phase ran from his initial writings up to the early 1980's. In On Social Identity ${ }^{1}$ and Theory of Communicative Action, ${ }^{2}$ Habermas was critical of religious faith. Still influenced by the Marxist theory he inherited from the Frankfurt School, he viewed religion as an "alienating reality." With its dualist view of the world and claim that other-worldly salvation was more important than this-world happiness, religion had always served as a tool of the powerful. This critique was part of his broader philosophic agenda. Habermas hoped for the "disappearance" of religion. To provide men liberty, modern society needed to escape the empire of metaphysics and rely on the resources of communicative rationality, which are built on "principles of the secular universal ethic of responsibility."

The second stage lasted roughly from 1985 to 2000 . Habermas now replaced the hope for "disappearance" with a call for "privatization." In texts such as "Post-Metaphysical Thought" (1988) he reminded his readers that religion is an existential necessity that is "indispensable in ordinary life." In the face of suffering, it is only natural for people to turn to faith. While not personally "religiously motivated," Habermas understood that for a good part of the population religion offers "consolation." Nonetheless, religious people

\footnotetext{
$\overline{1}$ Jürgen Habermas, «On social identity», Telos, 19, 1974, p.90-103.

${ }^{2}$ Id., Théorie de l'agir communicationnel, Paris, Fayard, 1987 [1981].
}

P. Portier $(\bowtie)$

46, rue de Lille,

75007 Paris, France

e-mail: philippe.portier@gsrl.cnrs.fr should not bring their convictions into the political domain. In the public square, secular reason is sufficient. Religion, which is defined by particular beliefs, cannot claim to apply universally nor be justified rationally. ${ }^{3}$

In the late 1990's Habermas' position underwent its third and final change, which is reflected in such works as The Future of Human Nature and Naturalism and Religion. ${ }^{4}$ Habermas now supported the notion of "publicization." Under this rubric, he stressed that religion should not be limited to the private sphere. Rather, it should intervene in the public sphere and use its founding documents and traditions to refine "moral intuitions." This third phase of Habermas' thought predicts the coming of a "post-secular society," in which individuals, without abdicating their autonomy, rediscover a sense of transcendence and religious belonging.

What led to these changes of theoretical position? There are three principal sources. The first is the fruit of sociological analysis. For Habermas, the "secularization" thesis no longer fits reality. Its claim that religion was destined to fade from history does not comport with "the self-understanding that men have of themselves." Although marked subjectivism, all societies retain significant attachments to their religious roots. As José Casanova has shown, even Western societies are increasingly asking their Churches to intervene in the public square. ${ }^{5}$ Without wishing to subordinate the realm of values to that of facts, Habermas nonetheless considers it incumbent on political

\footnotetext{
${ }^{3} I d$., «Transcendence from within, Transcendence in this world» in Don Browning and Francis Schüssler Fiorenza, Habermas, Modernity and Public Theology, New York, Crossroad, 1992, p.230 sq.

${ }^{4}$ Id., L'avenir de la nature humaine, Paris, Gallimard, 2002 [2001]; Entre Naturalisme et religion, Paris, Gallimard, 2008 [2005].

${ }^{5}$ José Casanova, Public Religions in the Modern World, Chicago, The University of Chicago Press, 1994.
} 
philosophy to attend to this fundamental reality, and to seek an appropriate legal framework to accommodate it.

Habermas' evolution is also the product of his concern for the sources of values. He has long held that social conflicts could be resolved by the simply exchanging secular arguments. ${ }^{6}$ His positivist philosophy of history envisaged three eras: the era of mythology, the era of metaphysics, and the era of rationality. In the 1990s, however, he began to sense the inadequacy of agnostic reason for confronting the new challenges posed by the expansion of capitalism and the progress of science. To solve the problems of technological development and the growth of poverty, society must also rely on "moral intuitions" and on "reserves of meaning," which have been maintained by religious systems.

Finally, in the early 1990s, intellectual controversy influenced Habermas' thought. His work was subjected to forceful theological-political criticism, most notably by American thinkers. David Tracy, for example, argued that religion, especially Christianity, cannot be reduced merely to the "appeasement of private suffering." Rather, it contains the normative resources necessary for "civilizing" global society. ${ }^{7}$ William Meyer adds that, contrary to what Habermas had initially maintained, religion is not reducible to particular communities, but has the capacity to interpret and give meaning on a universal basis. ${ }^{8}$ Always governed by the rule of the "best argument," Habermas was not indifferent to these criticisms and quickly addressed them in his own philosophical system.

The introduction of a religious dimension into Habermas' thought is controversial. Is it a minor change that does not fundamentally challenge the "subjectivism" of his early theories? Or, on the contrary, does it represent a radical turn to an essentialist mode of thought? ${ }^{9}$ In what follows, I propose a position between these alternatives. There has indeed been a real transformation in Habermas' thought. But it has occurred within a modern body of ideas that remains committed to the principle of the autonomy of politics.

\section{Going Beyond Secular Separation}

In his later works Habermas often uses the word "secular," or laïciste in French. It designates a specific pattern of

\footnotetext{
${ }^{6}$ For example Droit et démocratie, Paris, Gallimard, 1997 [1992].

${ }^{7}$ David Tracy, «Theology, Critical Social Theory, and the Public Realm», in Don Browning and Francis Schüssler Fiorenza, op. cit., p.36.

${ }^{8}$ William Meyer, «Private Faith or Public Religion? An Assessment of Habermas 's Changing View of Religion», The Journal of Religion, 75, 3, 1995, p.371-395.

${ }^{9}$ Paolo Flores d'Arcais, «Onze thèses contre Habermas», Le Débat, nov.-déc. 2008, p.16-31.
}

collective life that is organized-far from the influence "archaic residue" of religion - solely on the basis of an exchange of reasons. Habermas, as noted above, had long been attached to this conception of politics. Today this is no longer the case. He now willingly concedes that "thought illuminated by naked reason" has shown "all its limitations," and should therefore be overcome by an increased reliance on religious foundations.

\section{The Fragility of Secular Reason}

The texts of Adorno and Horkheimer, especially The Dialectic of Reason, have continued to influence Habermas's work in recent years. The Enlightenment is obviously an important moment in the history of liberty. It freed men from traditional authorities and allowed them to invent for themselves the norms and standards of their own existence. Yet, in forcing each individual back on himself alone, it led the world to a logic of excess and failed to keep its promise of emancipation.

The modern world, such as it is constituted by Kant, possesses, in Habermas' view, a double quality. ${ }^{10}$ First, it is a universe of autonomy. In the "metaphysical" age, people thought that "the structure of the cosmos and human nature would provide the basic elements for establishing the normative frameworks of the life one should live." 11 The individual was required to adopt moral positions that he had not necessarily chosen. And if he resisted these injunctions, the State and the Church were there to put him back on the straight and narrow. The new world of liberalism ended man's confinement within an objective order and abolished the idea of "pre-political foundation." At the level of the community, it tried to institute the "political autonomy of citizens," where law emerges solely from debate among "free and equal beings." At the individual level, since man is both the author and subject of the law, he cannot seek to abolish the freedom of those who live under the law he creates. Everyone in this new order finds his autonomous choices respected. As Habermas puts it: "Everyone must lead his own life according to his own preferences and convictions."

But the modern world is also, initially, one of solidarity. Obviously, in the old society people cared about others: no one was permitted to live only for himself. Nonetheless, the individual did not really choose this solidarity; rather, the group imposed it on him. Modern solidarity, by contrast, is

\footnotetext{
${ }^{10}$ This point is clarified in Philippe Portier, «Liberté et religion dans la pensée de Jürgen Habermas», Politeia, n ${ }^{\circ}$, 2006, p. 251-267.

${ }^{11}$ Jürgen Habermas, L'avenir de la nature humaine, Paris, Gallimard, 2002, p.10.
} 
not prescribed. It proceeds from the free conscience of each individual, which gives it an added "ethical value." Two principles clarify how this solidarity is actualized. On the one hand, it builds on the principle of participation. "In identifying communicative freedoms," Habermas writes, "constitutional democracy mobilizes citizens' participation in public confrontations over issues that concern everyone." 12 Habermas thus holds that a decision-making process based on verbal exchange brings people together, not only because it obliges them to seek rational solutions acceptable to everyone, but also because it leads them to see each other as possessed of equal dignity. On the other hand, solidarity is linked to the principle of reciprocity. ${ }^{13} \mathrm{In}$ its Kantian origins, constitutional democracy is based on otherness more than utility. The "categorical imperative" mandates a "moral community" in which men "are treated as ends in themselves," and "would not accept to be free when others are not." "14 Yet that ideal has collided with reality. "Mutual understanding" has not materialized. In the contemporary world, we are faced with the "intolerable conditions" of marginalization, exclusion, insecurity, and unemployment. Habermas summarizes the situation with the following formula: "Modernization has derailed to the point where it has eliminated any type of solidarity that it aimed to promote." 15

There are two intertwined reasons for this outcome. According to Habermas, the major "mediums of social integration," markets and politics, are dysfunctional. The economy is now hegemonic. It "works more like a medium that controls every aspect of life." ${ }^{16}$ No sphere of activity, not even health and education, can escape the empire of merchandise. Politics, according to Habermas, becomes secondary. It is relieved from the regulatory function of private interests to supporting, along with the bureaucracy, moneyed interests. The dismantling of the welfare state throughout the West reflects the retreat of the public sector.

These social processes are inseparable from cultural processes, which are even more decisive. Following Kant, Habermas asserts that deliberation has an essential role to play in constitutional democracy. Based on "communicative reason," it should subordinate politics and markets to the imperative of solidarity. However, according to Habermas, deliberation no longer performs that function. Rather, everything indicates that it tends to strengthen the dominance of the existing order. The poor usually do not even participate in the discussion, further contributing to their socio-economic marginalization. Even engaged citizens do

\footnotetext{
$\overline{12 \text { Ibid., p.10-11. }}$

${ }^{13}$ Id., L'éthique de la discussion et la question de la vérité, Paris, Grasset, 2003, p.19.

${ }_{15}$ Ibid., p. 21.

15 «Pluralisme et morale», art. cit. p.12.

${ }^{16}$ Ibid.
}

not participate on the basis of communicative reason but follow a "strategic" logic to defend their own interests: "They brandish their individual rights as weapons against each other," losing "any sense of concern for social pathologies." in our societies. It is the triumph of utilitarian freedom, where individuals "center" themselves around their own ego. ${ }^{18}$

This situation is the result of the limited character of the ego (what Kant called the "unsocial sociability of man") and the product of capitalism's ideological effects, which cry out for a response. Religion can provide one.

\section{The Rediscovery of Religious Language}

In light of the contemporary crisis, how can we rebuild "a legitimate world of interpersonal relationships"? Habermas no longer believes we can rely on "the anonymous gods of post-hegelian metaphysics," which is to say the Marxist model of intelligence and the transformation of the world. ${ }^{19}$ (He had already come to this conclusion in the 1960s when, making his linguistic turn, he had discovered the ethics of discussion). Instead, we must have recourse to religion. The religion to which he refers is the "true" religion, which, in a Weberian manner, he holds is structured around a relationship with the transcendent. He references religions of the Axial Age (Karl Jaspers), Judaism and Christianity in particular, and to a lesser extent Islam: "In relation to these religious traditions, democracy has good reason to hold itself ready to learn." 20

This plan of recognizing the importance of religion is justified by two kinds of reasons. The first concerns personal development. Habermas returns to the idea that a democratic society must respect the aspirations of believers and nonbelievers alike: "The liberal state should not impose asymmetric religious obligations on its citizens." ${ }^{21}$ Habermas thus espouses a classic view of civil rights: the opinions of every citizen must be respected. The code of liberal democracy is that the state must be neutral regarding different worldviews. Church and State must be separated and political power is bound to accept the pluralism of opinions and beliefs.

Habermas clarifies his views by repeating the common distinction, already introduced by Tocqueville, between the French and the American experience. The American

\footnotetext{
${ }^{17}$ Ibid

${ }^{18}$ For Habermas, this development is linked with the progress of naturalism in modern science, which contributes to the destruction of moral standards, in particular personal dignity. See chapter 1 of Entre naturalisme et religion.

${ }^{19}$ Id., «Pluralisme et morale», p.15.

${ }^{20} \mathrm{Ibid}$.

${ }^{21}$ Entre naturalisme et religion, op.cit. p.149.
} 
experience is problematic in some ways. As the United States is attached to the distinction between the sphere of the state and the public sphere, Habermas does not understand how the American president can swear on the Bible and pray in public. However, regarding the basic democratic ideal, America's model is more complete than the French one. Since the Revolution of 1789, France has been organized such that the state is the legal guardian of religion. This can have the effect of reducing freedom. Following Thomas Jefferson, the United States instead built on the idea that everything must be done to keep the state separate from the religious sphere and give the largest provide scope possible for the development of religious beliefs.

Habermas also turns his attention to the more recent focus on cultural rights. Citing theorists of recognition like Will Kymlicka, he holds that far from wanting to be reduced to mere consciousness or a self without content, the individual also aims to define himself according to a cultural or religious identity that he has been given by the cultural milieu by which he was socialized. Another trend in the West is that people increasingly claim an attachment to a previous culture that is often religiously determined. Could the liberal state conceivably hinder the desire for identity? Certainly not, says Habermas. The state establishes the fundamental right of everyone to "live according to his complexion" as long as the identity is chosen by the individual and does not undermine the foundations of constitutional order. In Naturalism and Religion he argues, "We must derive the cultural rights from the principle of the inviolability of human dignity." 22

The second set of reasons concerns societal "civilization." Secular thought holds that religions "produce social pathologies" instead of freeing us from them. Habermas argues that we should reject this claim. More than many care to admit, religious systems contributed to the emancipation of man. First, they invented the idea of freedom. Religious institutions have sometimes been "hindrances" to freedom. However, at least in the case of Judaism and Christianity, their holy texts have helped to "disenchant magic and overcome myth" and to produce new normative concepts such as "responsibility, autonomy, individuality." 23 They have enabled societies to escape the omnipotence of transcendence and open them up to the logic of human rights. Habermas departs from the "enlightened" philosophy of history that holds that the Enlightenment was purely secular and detached from any predetermination by religious thought.

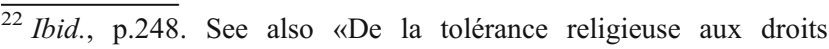
culturels», Cités, 13, 2003, p.147-177.

${ }^{23}$ Id., L'avenir de la nature humaine, p.65.
}

In addition, religion has helped to establish the idea of solidarity. It has countered alienation and helped to rebuild a "mode of living" where all get their due. "It grasps the symptoms of a failed life" and "constitutes a source of culture which can promote standards of consciousness and citizen solidarity." ${ }^{24}$ Current conditions make the presence of religion even more necessary, because colonization of the world by "turbo-capitalism" and technology has intensified human subjugation. Because of the rise in the power of utilitarianism and the silence of intellectuals, ${ }^{25}$ we have "lost all clinical definitions for social pathologies." ${ }^{26}$ These reflections, Habermas points out, build on ideas of thinkers like Walter Benjamin and Ernst Bloch, who in their own time had resisted the rule of traditional atheism and had accorded "religious images a potential truth." 27

Some have seen in this mode of argument, which is based on the idea of man's loss of his original nature and of its possible regeneration through religion, an indication that Habermas has surrendered to a view in which faith would subsume reason. ${ }^{28}$ But this is not, I would argue, Habermas' purpose. Even if he concedes that religion should play a role in history, it is not the same kind of role as envisioned by Karol Wojtyla or Joseph Ratzinger. Like Kant, Habermas views faith as a complement to reason, not as its basis.

\section{The Refusal of Metaphysical Entrapment}

Joseph Ratzinger held that Grotius principle of Etsi Deus non daretur $^{29}$ is the exact opposite of Sicuti daretur Deus-"Act as if God exists." The words are a warning. In the face of modern thought that seeks to place man solely under the rule of natural reason, reason must be prevented from going off the rails by a transcendent standard. Habermas recognizes religion as the source of a civilized life, but he insists that it should not be in a position to govern politics. His view operates on two levels: on the plane of religious belief, society must not impose a single standard of behavior on its citizens; on the plane of the institutional order, the State must be free to act beyond any kind of submission to positions of communities of belief.

\footnotetext{
${ }^{24}$ Id., «Pluralisme et morale», p. 18.

${ }^{25} I d$., «Retour sur la religion dans l'espace public», Le Débat, nov.déc. 2008, p.29.

${ }^{26}$ Id., «Pluralisme et morale», p. 18.

${ }^{27} I d$., «Retour sur la religion dans l'espace public», Le Débat, nov.déc. 2008, p.28.

${ }^{28}$ Besides Paolo Flores d'Arcais, see S. Dimitru Nalin, «Liberté de procréation et manipulation génétique. Pour une critique d'Habermas», Raisons politiques, $\mathrm{n}^{\circ} 12$, nov.2003, p.31-53.

29 «Act as if God doesn't exist»
} 


\section{The Denial of Cultural Homogeneity}

Habermas has argued against conservative authors who have at one time or another denounced liberal democracy. He points in particular to Schmitt, Heidegger, and the German jurist Böckenförde, who was close to John Paul II. In Law, State, and Freedom, Böckenförde advanced his thesis that democracy is doomed to descend into anomie if it is not based on a "unifying bond that constitutes the prerequisite for freedom." For Böckenförde, society's collective ethics must be embedded in "moral or religious traditions that involve collective obligations."

Habermas rejects societal homogenization. First, he believes that it is socially unworkable. In the words of John Rawls, the world is marked by the fact of pluralism, especially cultural pluralism. With globalization and "the influx of refugees from cultures with a strong traditional imprint," ${ }^{30}$ Western societies have effectively become mosaics, divided into a multiplicity of lifestyles. This is not simply a sectarian division, as was the case with the partition of Europe between Catholics and Protestants. Individuals and groups are separated not only by their different approaches to the Church and salvation, but also by profoundly different "ways of thinking, feeling, and acting." Habermas focuses above all on the effects of the arrival of Muslims in Europe.

But our world is also facing another type of pluralism. It stems from the different convictions people hold. Habermas finds that a part of the population is perennially rooted in faith. Nonbelievers sometimes even return to certain forms of religious adherence. However, this only affects a fraction of the Western population. Many are now outside circles of belief. They often develop a secular morality committed to the principles of hedonism or utilitarianism. The debate in bioethics attests to this "war of the gods." The contest is between those who intend to bring life under an objective standard of conduct and those who want to leave its determination to an "exclusive humanism." This practical situation excludes every effort of a reduction to unity. Except through the use of force, Habermas believes, it is impossible to return to a homogeneous society.

The conservative view is also morally unacceptable. The first problem is the conception of man upon which conservatism rests. Böckenförde links human dignity to the "creatureliness" axiom. ${ }^{31}$ Man only accepts his lot after acknowledging his dependence on his Creator and begins to behave according to divine law. On the contrary, Habermas advocates the principle of "artificiality." Like Fichte, he believes that "man is accidentally minor and originally

\footnotetext{
${ }^{30}$ Jürgen Habermas, « Qu'est-ce qu'une société post-séculière?», Le Débat, nov.-déc. 2008, p.6.

${ }^{31}$ Id., L'avenir de la nature humaine, p.165.
}

major." The role of man is to build the moral order in which he lives. Far removed from the injunctions of traditional authorities, he only has the support of his decision-making ability. This conception of man leads to an open approach to history. We cannot fix things through reference to a world that once was. One must be able to "introduce the novel" into the movement of the world. ${ }^{32}$

The traditional conception of the state developed by Böckenförde broadens the theory of the subject. He holds that political power directs its legal output through natural law. Habermas rejects this idea because it seems contrary to the imperative of freedom. Political society must be organized by aggregating "free and equal persons" through debate rather than transcendence. "In a democracy," Habermas writes, "the subject of sovereignty is not fed by a pre-political substance." ${ }^{33}$ Based solely on the exchange of autonomous reason, does one risk leading society into chaos and injustice? Such is the concern of conservatives. But it is not Habermas' view. Democracy, if it remains open to all forms of wisdom, can produce sufficient communal bonds and meaning: "A pluralistic community can find legal stability by assuming a limited formal consensus regarding procedures and principles., 34

Overall, then, it is wrong to speak of an essentialist turning point in Habermas' thought. His model remains procedural. Far from imposing on men and society an external norm, the origin of government decision-making remains the exchange of words. In addition, he considers that the state can and should be neutral regarding different moral visions of the world. His model does not lead him to espouse a 'decisionist' conception of law. Debate cannot turn against its founding principles, which are freedom and equality among persons. ${ }^{35}$ In that respect, if one must appeal to religion, it is to ask it to strengthen the autonomy of the individual. ${ }^{36}$

\section{The Preservation of Institutional Separation}

How can one simultaneously stand for political neutrality and for the presence of religion? An answer requires

\footnotetext{
${ }^{32}$ Ibid.

33 «Pluralisme et morale», art. cit. p.7.

${ }^{34}$ Ibid.

${ }^{35}$ In Droit et république, Jürgen Habermas clearly articulates this position. He maintains that discussion is a means of learning norms, but also states that this discussion supposes respect for equality and the liberty of others who participate.

${ }^{36}$ See, Philippe Portier, «Les humanismes occidentaux face aux biotechnologies», in Jelloul Daghfous (dir.), Bioéthique et valeurs culturelles, Tunis, Editions de l'Académie de Carthage, 2010. This study seeks to show that Habermas' position against genetic technology, especially cloning, is founded not on an "ancient" or teleological conception, but rather on a modern one. The destiny of the person to be born is determined by a will other than his own.
} 
thinking institutionally. One of the major contributions of constitutional democracy is that churches are not allowed to penetrate or encompass the state apparatus. Habermas supports this idea and elaborates a dual schema of separation based on legal and linguistic rules.

As for the legal realm, the State, according to Habermas, should not preclude relationships with communities of faith, as is the case under the position of "absolute secularism." Habermas would like the separation to work "in the German way," meaning in a spirit of partnership. Beyond the fact that the State must recognize the fundamental rights of religious communities (such as assigning different roles to men and women), including the right to organize and develop, it can go so far as to support them financially and establish an open and regular dialogue with their representatives in order to reap their "resources of wisdom." Habermas also takes seriously the issue of cultural rights. Individuals should be able to freely exercise the social traditions to which they are attached, as in modes of dress, the ritual slaughter of animals, or dietary restrictions.

There is nothing here that indicates a policy of heteronomy or subordination to religious law. Religious authority cannot permeate the state apparatus (as is the case in Iran today) and then dictate the legal content. The standards imposed by governmental authority must be autonomous from religious decrees and must uphold the principles of equality and freedom that characterize constitutional democracy. For Habermas, the recognition of cultural traditions is only valid within the normative purview of constitutional democracy. Cultural traditions that are contrary to the republican law, such as "arranged marriages" or bodily mutilation must be denounced. In this vein, Habermas laments the U.S. Supreme Court ruling in Wisconsin v. Yoder (1972) that gave the Amish the right to exempt their children from public education after the age of fourteen. Habermas thus marks his distance from "strong" multiculturalist thinking, which recognizes collective rights and legal pluralism.

In regard to the second point-concerning the rules of language-Habermas shows the same desire to limit the expansion of religion. This issue can be approached by considering the distinction between the sphere of political decision (the state) and that of opinion formation (public space). ${ }^{37}$ For analysts like Nicolas Walterstorff, religious language should be present in both spheres; laws based on theological or even scriptural arguments are not prohibited. ${ }^{38}$ Others like Robert Audi, who believe that democracy must be based on the search for consensus,

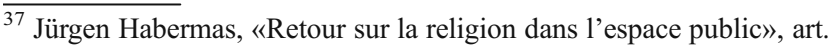
cit., p.29.

${ }^{38}$ Nicholas Walterstorff, Religion in the Public Square: The Place of Religious Convictions in Political Debate, Rowman \& Littlefield Publishers, 1996.
}

hold that the use of religious vocabulary should be avoided in both spheres. Audi defends what he calls "the principle of secular rationale," meaning that, "one has a prima facie obligation not to advocate or support any law or public policy that restricts human conduct unless one has, and is willing to offer, adequate secular reason for this advocacy or support." 39

Habermas proposes a middle course between these alternatives. The language of faith must remain outside the sphere of political decision-making. He takes up a proviso dear to John Rawls. In a democracy neither the government nor the bureaucracy nor the judiciary can make use of religious arguments to justify their actions, first because this would challenge the idea of "state neutrality with respect to world views," and second because "the law must be justified in a language that all people understand. ${ }^{40}$ From this perspective, Habermas is very critical of the rituals of "civic religion" in the United States, especially swearing on the Bible. In contrast, he does not seek to exclude religious speech from public discussion. Undoubtedly this is for reasons of equity: "The solidarity between members of a democratic community requires that in secular civil society and the public policy sphere citizens can meet their religious fellow citizens as equals." ${ }^{41} \mathrm{He}$ adds that religious language is also useful. Drawing from their rhetorical wells of meaning, religions can further enhance the civilizing impact of their proposals, helping the "civic dialogue" to achieve "rationally acceptable results." Examples here include the idea of Creation that elevates the sacredness of human beings.

The general pattern involves a conversion of communities of belief. Just as nonbelievers must open themselves to the cognitive contributions of religion, Habermas holds that religious communities must engage in an "apprenticeship" to learn democratic principles. Religious communities must respect the autonomy of their members. Habermas not only denounces the pretensions of Iranian and Afghan mullahs, but also the priests of the Solidarity movement or German bishops who gave electoral instructions to their flock in the Adenauer era. As he puts it: "Churches are not allowed to substitute their spiritual authority for reasons likely to find a broad resonance." They should adhere to the principles of liberalism, including "sustainable dissensus" (or pluralism)

\footnotetext{
$\overline{39}$ Robert Audi, "The place of religion argument in a free and democratic society", San Diego Law Review 30 (1993), p.691-692.

${ }^{40}$ Entre naturalisme et religion, p. 180.

${ }^{41} I d$., «Retour sur la religion dans l'espace public», Le Débat, nov.déc. 2008 , p.149. On this point, we must notice another agreement with John Rawls. At odds with his previous "exclusive position", Rawls recognizes in Political Liberalism, lesson 6 (New York, Columbia University Press, 1993), the legitimacy of the inclusive position, which permits citizens to use religious arguments in the public debate if "these arguments strengthen the ideal of public reason."
} 
and "deliberation as a source of law" (popular sovereignty). For Habermas, these principles are not simply conveniences, as they were for the Catholic Church before Vatican II (with its model of restrictive tolerance). It is an in-depth and sincere conversion, insofar as "the constitutional state, far from satisfying a modus vivendi, depends on a legitimacy rooted in conviction." 42

In sum, there has been a shift in Jürgen Habermas' thought. A defender of secularism up to the 1990s, he situates himself today among the proponents of a postsecular society. His recent writings take issue with "hardened and exclusive" secularism. Breaking with strict separationists, he agrees that cooperative relations can be established between the Church and State. He also strongly defends the value of religious input in creating a civilization. Habermas argues that the "loss of function" of religion does not lead to its "loss of meaning." But this recognition does not reflect a tendency towards essentialist thought; Habermas remains within the space of "post-metaphysical" modernity. He does not envision a theocratic regeneration of society, which has been rendered impossible by the continuing process of detachment from strong religious views (and by individualization of behavior). For Habermas, politics must retain its autonomy. Consistent with Kant's view, religion should implant itself "within the limits of reason." Today, Jürgen Habermas' thought, by his own admission, has encountered and taken into account a current of contemporary philosophy represented by such thinkers as Ricoeur, Walzer, and Taylor. Utilitarianism's excesses, he agrees, have led to social pathologies. The alliance of agnostic reason (provided it espouses solidarity) and reason animated by belief (provided it does justice to reason) must be combined to re-civilize the world.

Translated by Mark McNaught.

Philippe Portier is director of studies at the Ecole pratique des hautes études (Paris-sorbonne) and director of the religion and secularism group at the Centre National de la Recheche Scientifique (CNRS). He is also professor of political science at Sciences-Po Paris. He has published most recently La modernité contre la religion? (Presses Universitaires de Rennes, 2010), Pluralisme religieux et citoyenneté (Presses Universitaires de Rennes, 2010), Religion et théorie de l'évolution (Riveneuve, 2011). Mark McNaught holds a doctorate in political science from the Université Bordeaux IV and is an assistant professor of American Civilization at the University of Rennes II. He also teaches law at the Fondation National de Sciences Politiques in Paris.

$\overline{42}$ Id., Entre naturalisme et religion, p.148. 